\title{
TINJAUAN YURIDIS TERHADAP SISTEM PERBANKAN DALAM PENCEGAHAN TINDAK PIDANA PENCUCIAN UANG MENURUT UNDANG UNDANG NOMOR 8 TAHUN 2010 TENTANG PENCEGAHAN DAN PEMBERANTASAN TINDAK PIDANA PENCUCIAN UANG
}

\author{
Oleh: Dhevi Nayasari Sastradinata, SH, MH
}

\begin{abstract}
Abstrak
Lembaga perbankan melalui mekanisme sitem perbankan dapat turut andil dalam mencegah dan memberantas praktek tindak pidana pencucian uang yaitu dengan melaksanakan prinsip prinsip mengenal nasabah. Selain itu untuk pemaksimalan pihak perbankan dalam mengantisipasi tindak pidana pencucian uang dapat melibatkan institusi-institusi lain seperti kepolisian dan sejenisnya.

Upaya pencegahan dan pemberantasan atas tindak pidana pencucian uang juga dapat dilakukan melalui mekanisme pengaturan. Dalam hal ini upaya itu dilakukan oleh pemerintah dengan membentuk suatu perundang-undanga yang husus membahas mengenai isu TPPU tersebut yang selalu mengalami perubahan sesuai perkembanganya. Dan sesuai isi dari bentuk terbaru perundang-undangan tentang TPPU ada beberapa hal yg perlu dicermati dalam usaha pemberantasan dan pencegahan atas TPPU yaitu :

- Penerapan prinsip-prinsip KYC pada system perbankan

- $\quad$ Menjalin komunikasi antar lembaga yang telibat dalam urusan TPPU

- Pengoptimalan lembaga pengawas yang mandiri seperti halnya PPATK sebagai kontroling atas peredaran dan lalu lintas transaksi keuangan.
\end{abstract}

Kata kunci : Sistem perbankan, Pencegahan Tindak Pidana Pencucian Uang, Undang undang nomor 8 Tahun 2010.

\section{Pendahuluan}

kata bank berasal dari bahasa italy "banca" yang berarti benca,yaitu suatu bangku tempat duduk. Sebab pihak bankir italy yang tersebut memberikan pinjamanpinjaman melakukan usahanya tersebut dengan duduk di bangku-bangku di halaman pasar. Istilah bank dimaksudkan suatu jenis pranata finansial yang melaksanakan jasajasa keuangan cukup beraneka ragam, seperti pinjaman, memberikan pinjaman, mengedarkan mata uang, mengadakan pengawasan terhadap mata uang, bertindak sebagai tempat penyimpanan untuk benda benda berharga, dan membiayai prusahaan. ${ }^{1}$

bank juga sebagai suatu institusi yang mempunyai peran yang besar dalam dunia

\footnotetext{
${ }^{1}$ Munir Fuady, hukum perbankan Modren, Citra Aditya Bakti, Bandung 2003,hal,13
}

perekonomin, yang dalam suatu fakta historis bahwa proses pembentukan UndangUndang perbankan dilakukan pada masamasa tidak normal, sehingga menjadikan hal tersebut secara langsung atau tidak langsung berpengaruh terhadap materi UndangUndang yang bersangkutan

Kegiatan bank umum yang terdiri dari kegiatan utama dan kegiatan tambahan dan kegiatan bank perkreditan Rakyat yang menjadi pokok dari suatu bank ; menarik dana dari masyarakat dalam bentuk giro, deposito, sertifikat deposito, tabungan, dan bentuk-bentuk lainya, menyalurkan dana lewat pemberian kredit, menerbitkan surat pengakuan hutang, membeli, menjual, atau menjamin atas resiko sendiri atau atas kepentingan nasabah. Hal ini di sebabkan hakikat dari dunia perbanka bahwa dunia tersebut haruslah di atur dan diawasi secara ketat, karena dunia perbankan tersebut 
menyangkut dengan sekian banyak dana masyarakat bahka menyangkut hidup matinya prekonomian Negara. ${ }^{2}$

Dengan adanya globalisasi sekarang ini, dana hasil kejahatan mengalir atau bergerak melampaui batas yurisdiksi negara dengan memanfaatkan faktor rahasia bank yang pada umumnya dijunjung tinggi oleh perbankan. Sementara itu kegiatan pencucian uang hasil perdagangan obat bius, prostitusi, korupsi dan kejahatan lainnya sebagian besar diproses melalui perbankan untuk kemudian dikonversikan menjadi dana legal

Adapun pokok permasalahan dalam hal ini adalah :

1. Bagaimana upaya-upaya yang di lakukan oleh bank dalam melaksanakan mengenal nasabah pada transaksi perbankan?

2. Bagaimana pengaturan hukum tentang TPPU sebagai usaha pencegahan tindak pidana pencucian uang?

Tuhuan dari penelitian ini yaitu untuk mengetahui bagaimanakah pengaturan hukum tentang Tindak Pidana Pencucian Uang dan bagaimanakah bank dapat ikut berperan dalam usaha pencegahan kegiatan TPPU tersebut.

Jenis penelitian yang dipakai adalah normative. Yaitu suatu prosedur penelitian ilmiah untuk menemukan kebenaran berdasarkan logika keilmuan hukum dari sisi normatif ${ }^{3}$.

Metode pendekatan yang dipakai dalam penulisan ini adalah pendekatan perundangundangan. (Statute Approach) Pendekatan tersebut melakukan pengkajian pengaturan perundang-undangan yang berhubungan dengan pokok permasalahan. Selain itu juga digunakan pendekatan konsep (consep approach).

\section{Pembahasan}

${ }^{2}$ Ibid hal 7

${ }^{3}$ Peter Mahmud Marzuki. Penelitian

Hukum. kencana. Surabaya. 2010. Hal. 47
Perbankan adalah lembaga keungan yang berperan sangat vital dalam aktivitas perdagangan internasional serta pembangunan nasional. Pada dunia ekonomi modern saat ini, masyarakat sangat bank minded. Ini dapat dilihat dari makin maraknya minat masyarakat untuk menyimpan, berbisnis, bahkan sampai berinvestasi melalui perbankan. Hal ini menyebabkan semakin maraknya dunia perbankan yang dapat dilihat dari tumbuhnya bank-bank swasta baru walaupun pemerintah semakin memperketat regulasi pada dunia perbankan.

Menurut Kuncoro dalam bukunya Manajemen Perbankan, Teori dan Aplikasi (2002: 68), definisi dari bank adalah lembaga keuangan yang usaha pokoknya adalah menghimpun dana dan menyalurkan kembali dana tersebut ke masyarakat dalam bentuk kredit serta memberikan jasa-jasa dalam lalu lintas pembayaran dan peredaran uang. ${ }^{4}$

Menurut Dr.(Cand.) Taswan, S.E.,M.Si, Bank diartikan sebagai sebuah lembaga atau perusahaan yang aktivitasnya menghimpun dana berupa giro, deposito tabungan dan simpanan yang lain dari pihak yang memiliki kelebihan dana (surplus spending unit) kemudian menempatkannya kembali kepada masyarakat yang membutuhkan dana (deficit spending unit). Dan Perbankan adalah segala sesuatu yang berkaitan dengan bank, mencakup kelembagaan, kegiatan usaha, serta cara dan proses dalam melaksanakan kegiatan usahanya. ${ }^{5}$

Menurut Undang-Undang No. 10 Tahun 1998, bank adalah badan usaha yang menghimpun dana dari masyarakat dalam bentuk simpanan dan menyalurkannya kepada masyarakat dalam bentuk kredit dan

\footnotetext{
${ }^{4}$ http://pandusamamaya. wordpress.com /2012/03/26/tugas-1-1-pengertian-bankklasifikasi-tugas-fungsi-serta-kegiatan-padabank/

${ }^{5}$ http://sekilasbank. Blogspot. Com /2010/12/ pengertian-bank-danperbankan.html
} 
atau bentuk lainnya dalam rangka meningkatkan taraf hidup rakyat banyak.

Sesuai UU RI No 10 Tahun 1998 tanggal 10 November 1998 tentang perbankan, dapat disimpulkan bahwa usaha perbankan meliputi tiga kegiatan, yaitu menghimpun dana, menyalurkan dana, dan memberikan jasa bank lainnya.

Perbankan dalam dunia ekonomi modern memiliki peran penting dan strategis bagi siapa saja yang menginginkan untuk menunjang perkembangan bisnisnya. Hal ini dikarnakan dalam perbankan melalui berbagai macam jasa yang ditawarkan membuat sebuah transaksi tak lagi berpaut jarak. Dan perbankan juga merupakan suatu lembaga perasurasian, dana pension, dan penggadaian

System perbankan dalam bentuk yang lebih sederhana sudah pernah ada pada tahun 200 SM. Bangsa yang menggunakan system ini adalah bangsa babilon. Pada waktu itu lembaga perbankan yang lebih dikenal dengan sebutan tempels of Babylon mempunyai suatu aktifitas berupa peminjaman emas dan perak dengan suku bunga $20 \%$ dari pinjaman awal yang ditarikan pada tiap bulan. Selain melakukan peminjaman yang berbunga mereka juga melakukan praktek pembayaran menggunakan yangsuatu instrument kredit yang dewasa ini kita kenaldengan istilah promissory atau cek. ${ }^{6}$

Seiring perkembangan praktek transaksi dengan model yang mirip dengan transaksi perbankan dewasa ini pun mengalami perkembangan. Bank pertama kali didirikan dalam bentuk seperti sebuah firma pada umumnya pada tahun 1690 pada saat kerajaan Inggris berkemauan merencanakan membangun kembali kekuatan armada lautnya untuk bersaing dengan kekuatan armada laut Perancis. Akan tetapi pemerintahan Inggris saat itu tidak mempunyai kemampuan pendanaan

\footnotetext{
${ }^{6}$ Munir fuady, hukum perbankan modern, PT. Citra Aditya Bakti, bandung, 2008, hal. 16
}

kemudian berdasarkan gagasan William paterson direalisasikan dengan membentuk sebuah lembaga intermediasi keuangan yang akhirnya dapat memenuhi dana pembiayaan tersebut hanya dalam waktu duabelas hari. ${ }^{7}$

Sedangkan sejarah hukum perbankan diindonesia sendiri berkibar sejak masuknya VOC. Yaitu suatu serikat dagang belanda yang melakukan aktifitas perdagangan di bumi nusantara kala itu. Namun meskipun praktek transaksi secara perbankan sudah berlaku sebuah lembaga yang berperan atau beroperasi sebagai bank baru didirikan pada tahun 1824. Yang kemudian pada tahun 1927 de javasche bank resmi berdiri sebagai bank pertama di Indonesia bank yang didirikan oleh pemerintah belanda inilah yang kemudian dewasa ini kita kenal dengan bank Indonesia. ${ }^{8}$

Pembahasan masalah pencegahan kejahatan yang mempergunakan sarana perbankan telah dimulai pada tanggal 27 juni tahun 1980. sistem perbankan dapat memainkan peranan yang efektif dalam pencegahan kejahatan, melalui koordinasi dengan lembaga yang bergerak di bidang hukum, seperti kepolisian dan lembaga peradilan sebagaimana tertuang dalam rekomendasinya "Recommendation No. R(80)10". Pada desember 1988 secara nyata di terbitkan konsep yang di kenal dengan "Prevention of Criminal Use of the Banking Syistem for the Purpose of money laundering".

Oleh karena itu sebuah Penerapan Prinsip Mengenal Nasabah (KNOW YOUR CUSTOMER PRINCIPLES). Atau seringnya disingkat dg istilah KYC sebagaimana Peraturan Bank Iindonesia (PBI) nomor 3/10/PBI/ 2010 yang kemudian dirubah dengan Peraturan Bank Indonesia Nomor 3/23/PBI/2001 dan disempurnakan lagi dengan Peraturan Bank Indonesia Nomor 5/

\footnotetext{
${ }^{7}$ http://id.wikipedia.org/wiki/Bank

${ }^{8}$ Munir fuady, hukum perbankan modern, PT. Citra Aditya Bakti, bandung, 2008, hal.25
} 
$21 / \mathrm{PBI} / 2003$ merupakan suatu hal penting yang harus diperhatikan oleh bank.

Kemudian KYC (KNOW YOUR CUSTOMER PRINCIPLES) sendiri diartikan sebagai suatu sarana bank untuk melakukan kontroling atas transaksi yang terjadi dan atau dilakukan oleh para nasabah. Atau juga bisa diartikan sebagai prinsip kehati-hatian. hal ini sebagaimana yang tertuang dalam pasal 1 ayat 2 dari Peraturan Bank Indonesia nomor 3/10/PBI/2001

"Prinsip Mengenal Nasabah adalah prinsip yang diterapkan Bank untuk mengetahui identitas nasabah, memantau kegiatan transaksi nasabah termasuk pelaporan transaksi yang mencurigakan;"

Secara lebih detail, usaha-usaha dan atau upaya yang dapat dilakukan perbankan dalam hal menjalankan prinsip pengenalan terhadap nasabah atau KYC (KNOW YOUR CUSTOMER PRINCIPLES) adalah sebagai berikut :

a. Menyusun kebijakan dan prosedur Penerapan Prinsip Mengenal Nasabah yang dituangkan dalam Pedoman Pelaksanaan Penerapan Prinsip Mengenal Nasabah dengan mengacu kepada Pedoman Standar Penerapan Prinsip Mengenal Nasabah yang ditetapkan dalam Surat Edaran Bank Indonesia;

b. Menetapkan dan menyampaikan Pedoman Pelaksanaan Penerapan Prinsip Mengenal Nasabah kepada Bank

c. Melaporkan pada Bi setiap perubahan yang dilakukan dalam menjalankan prinsip pengenalan nasabah dilingkunganya.

Money Laundry bukan uangnya di cuci di mesin cuci? Namun? Money Laundry atau Pencucian uang memiliki pengertian : Adalah setiap tindakan menempatkan, mentransfer, membayar, membelanjakan, menyumbangkan, mendepositokan, membawa ke luar negeri, menukarkan aset atau tindakan lainw yang di ketahui atau dicurigai sebagai hasil dari tindakan kejahatan supaya mengubah, menggelapkan atau menyamarkan sumber asset sehingga tampaknya berasal dari sumber yang sah atau legal.

Tindak pidana pencucian uang paling dominan dilakukan dengan menggunakan sistem keuangan. Perbankan merupakan channel yang paling menarik digunakan dalam kejahatan pencucian uang mengingat perbankan merupakan lembaga keuangan yang paling banyak menawarkan instrumen keuangan. Undang Undang Nomor 8 Tahun 2010 Tentang Pemberantasan dan Pencegahan Tindak Pidana Pencucian Uang sebagai bentuk terbaru dari instrument peraturan hukum yang mengatur tentang pemberantasan tindak pidana pencucian uang dalam usaha pencegahan terjadinya sebuah tppu memberikan suatu rumusan Materi muatan yang terdapat dalam UndangUndang Nomor 8 Tahun 2010 tentang Pencegahan dan Pemberantasan Tindak Pidana Pencucian Uang, antara lain:

1. redefinisi pengertian hal yang terkait dengan tindak pidana pencucian uang;

2. penyempurnaan kriminalisasi tindak pidana pencucian uang;

3. pengaturan mengenai penjatuhan sanksi pidana dan sanksi administratif;

4. pengukuhan penerapan prinsip mengenali Pengguna Jasa;

5. perluasan Pihak Pelapor;

6. penetapan mengenai jenis pelaporan oleh penyedia barang dan/atau jasa lainnya;

7. penataan mengenai Pengawasan Kepatuhan;

8. pemberian kewenangan kepada Pihak Pelapor untuk menunda transaksi;

9. perluasan kewenangan Direktorat Jenderal Bea dan Cukai terhadap pembawaan uang tunai dan instrumen pembayaran lain ke dalam atau ke luar daerah pabean;

10. pemberian kewenangan kepada penyidik tindak pidana asal untuk menyidik dugaan tindak pidana pencucian uang;

11. perluasan instansi yang berhak menerima hasil analisis atau pemeriksaan PPATK;

12. penataan kembali kelembagaan PPATK; 
13. penambahan kewenangan PPATK, termasuk kewenangan untuk menghentikan sementara Transaksi;

14. penataan kembali hukum acara pemeriksaan tindak pidana pencucian uang; dan

15. pengaturan mengenai penyitaan Harta Kekayaan yang berasal dari tindak pidana. $^{9}$

PPATK sebagai suatu lembaga yang secara eksplisit disebutkan dalam UndangUndang No.8 Tahun 2010 memiliki fungsi atau Tugas antara lain mengumpulkan, menyimpan, menghimpun, menganalisis, mengevaluasi informasi yang diperoleh berdasarkan Undang-undang No. 8 Tahun 2010; membuat pedoman mengenai tata cara pelaporan transaksi keuangan yang mencurigakan; memberikan nasihat dan bantuan kepada instansi lain yang berwenang mengenai informasi yang diperoleh sesaui ketentuan UU; memberikan rekomendasi kepada Pemerintah sehubungan dengan pencegahan dan pemberantasan tindak pidana pencucian uang; melaporkan hasil analisis terhadap transaksi keuangan yang berindikasi tindak pidana pencucian uang kepada Kepoliisan untuk kepentingan penyidikan dan Kejaksaan untuk kepentingan penuntutan dan pengawasan; membuat dan menyampaikan laporan mengenai analisis transaksi keuangan dan kegiatan lainnya secara berkala kepada Presiden, DPR dan lembaga yang berwenang melakukan pengawasan Penyedia Jasa Keuangan.k. ${ }^{10}$

\section{Penutup}

Kesimpulan yang dapat diambil yaitu:

1. Lembaga perbankan melalui mekanisme sitem perbankan dapat turut andil dalam mencegah dan memberantas praktek tindak pidana pencucian uang yaitu dengan melaksanakan prinsip prinsipmengenal nasabah. Selain itu untuk pemaksimalan pihak perbankan

9

${ }_{10}$ ttp://id.wikipedia.org/wiki/Pencucian_uang dalam mengantisipasi tindak pidana pencucian uang dapat melibatkan institusi-institusi lain seperti kepolisian dan sejenisnya.

2. Upaya pencegahan dan pemberantasan atas tindak pidana pencucian uang juga dapat dilakukan melalui mekanisme pengaturan. Dalam hal ini upaya itu dilakukan oleh pemerintah dengan membentuk suatu perundang-undanga yang husus membahas mengenai isu TPPU tersebut yang selalu mengalami perubahan sesuai perkembanganya. Dan sesuai isi dari bentuk terbaru perundangundangan tentang TPPU ada beberapa hal yg perlu dicermati dalam usaha pemberantasan dan pencegahan atas TPPU yaitu :

- Penerapan prinsip-prinsip KYC pada system perbankan

- Menjalin komunikasi antar lembaga yang telibat dalam urusan TPPU

- Pengoptimalan lembaga pengawas yang mandiri seperti halnya PPATK sebagai kontroling atas peredaran dan lalu lintas transaksi keuangan.

Sedangkan saran yang dapat diajukan adalah

A. Pemaksimalan penerapan prinsip mengenal nasabah dalam hal pengawasan transaksi membutuhkan perhatian lebih. Sebab sebaik apapun pengaturan dan program bila tidak dilengkapi dengan pengawasan akan berahir kurang maksimal.

B. Dalam hal ini PPATK seharusnya diberikan kewenangan yang lebih dalam menjalankan tugasnya, yaitu dengan diberikan kekuasaan untuk melakukan penyidikan, Mengingat banyaknya akses atau kemudahan yang di miliki oleh PPATK untuk melakukan hal ini. Diberikan kewenangan kepada PPATK untuk melakukan pembekuan transaksi secara langsung setela memperoleh laporan dari pihak-pihak laporan, terhadap transaksi yang di duga kuat merupakan tindak pidana pencucian uang. 


\section{Daftar Pustaka}

Peter Mahmud Marzuki. Penelitian Hukum. kencana. Surabaya

Munir fuady, hukum perbankan modern, PT. Citra Aditya Bakti, bandung

http://id.wikipedia.org/wiki/Pencucian_u ang

http://sekilasbank.blogspot.com/2010/12/ pengertian-bank-dan-perbankan.html

http://pandusamamaya. wordpress.com /2012/03/26/tugas-1-1-pengertian-bank-

klasifikasi-tugas-fungsi-serta-kegiatan-padabank 